\title{
Severe acute respiratory syndrome (SARS), Middle East respiratory syndrome (MERS), influenza, and COVID-19, beyond the lungs: a review article
}

\author{
Alecio F. Lombardi ${ }^{1} \cdot$ Amir M. Afsahi $^{1} \cdot$ Amit Gupta $^{2} \cdot$ Ali Gholamrezanezhad $^{3}$ (D)
}

Received: 17 August 2020 / Accepted: 15 November 2020 / Published online: 26 November 2020

(C) Italian Society of Medical Radiology 2020

\begin{abstract}
Background In the past 20 years four major viral infectious diseases outbreaks caused hundreds of thousands of deaths worldwide: SARS, Influenza H1N1, MERS, and COVID-19. They all present clinically initially as upper and lower respiratory tract infections and may progress to multi-organ failure.

Methods This study was a systematic review of literature conducted in September 2020 to study extra-pulmonary complications of SARS, FLU, MERS, and current COVID-19. We carried out a systematic search using the keywords in online databases of PubMed, EMBASE, and Google Scholar until June 2020.

Objective This article aims to review the most common extra-pulmonary manifestations of SARS, Influenza, MERS, and COVID-19.

Discussion Several studies have reported extra-pulmonary conditions in patients diagnosed with SARS, Influenza, MERS, and COVID-19, either by direct viral injury or from the systemic response to the initial infection.

Conclusion SARS, Influenza, MERS, and COVID-19 have all been associated with dysfunction of kidneys, endocrine system, neuromuscular symptoms, perinatal complications, and myocardial injury. Progression from pulmonary disease to a systemic condition has a poor outcome and can result in multi-organ failure.
\end{abstract}

Keywords COVID-19 $\cdot$ SARS $\cdot$ MERS $\cdot$ FLU $\cdot$ Extra-pulmonary $\cdot$ Complications $\cdot$ Pneumonia

\section{Introduction}

Recently severe acute viral infections have caused significant death toll globally through four major pandemics in the past 20 years. The severe acute respiratory syndrome (SARS) first appeared in 2002 and caused 774 deaths worldwide. In 2009 a new H1N1 influenza A virus caused another

Alecio F. Lombardi and Amir M. Afsahi equally contributed to the current study.

Ali Gholamrezanezhad

Ali.Gholamrezanezhad@med.ucsd.edu

1 Department of Radiology, University of California, San Diego, CA, USA

2 Department of Radiology, Case Western Reserve University, Cleveland, OH, USA

3 Department of Radiology, Keck School of Medicine, University of Southern California (USC), 1500 San Pablo Street, Health Sciences Campus, Los Angeles, CA, USA pandemic, affecting 60.8 million people and causing 12,469 deaths only in the USA. In 2012, a new coronavirus (MERS$\mathrm{CoV}$ ) was recognized to cause the Middle East respiratory syndrome (MERS) that presented with more than $30 \%$ mortality (858 reported deaths) and spread to 27 countries. In December 2019, a new coronavirus (SARS-CoV-2) surged in China, causing the current COVID-19 pandemic. The high viral infectivity caused the disease to spread throughout the world rapidly. More than 7.76 million cases in more than 188 countries, resulting in more than 429,000 deaths, have been reported to the present day. This article aims to review extra-pulmonary complications associated with these four viral outbreaks. Although the recent H1N1 pandemic was associated with only one type of influenza virus, the annual seasonal infectious epidemics make this a viral infection that is worth studying in a more comprehensive way. 


\section{Methods}

This study was a review of literature conveyed in August 2020. The authors studied the extra-pulmonary complications of SARS, FLU, MERS, and current COVID-19.

By systematic search of keywords in online databases of PubMed, EMBASE, and Google Scholar two independent researchers retrieved the most relevant peer-reviewed papers by titles and abstracts published in English until August 2020. The papers of non-human studies, suspicious of duplicated results, and papers with unavailable full texts excluded from our study. Finally, two independent researchers evaluated the quality of selected articles and the bias risk. In either case of discrepancy, a third independent researcher resolved the differences in viewpoints.

\section{Extra-pulmonary complications}

\section{Renal abnormalities}

MERS and SARS have been associated with acute kidney injury (AKI), possibly caused by virus tropism for the kidneys and secondary damage due to systemic inflammation and hypotension. In a retrospective study of 536 patients with a diagnosis of SARS, $6.7 \%$ presented with acute renal failure, of which eventually $91.7 \%$ died [1]. In another retrospective study with 30 patients diagnosed with MERS, eight (26.7\%) patients developed AKI, and $15(50 \%)$ showed proteinuria [2]. According to this study, older patients had higher incidence of AKI.

Direct involvement of kidneys by influenza viruses is a subject of debate. However, renal involvement in children with influenza A infection as a part of multiple organ dysfunction has been described in the past, suggesting that secondary injury is the most common pathophysiology of the renal disease [3]. Myoglobinuria and renal injury have been described as culprits in some case series $[4,5]$. Disseminated intravascular coagulation (DIC) and rhabdomyolysis were considered the cause of renal injury in one case series of influenza A patients, although the authors also discussed the difficulty in proving a direct involvement of kidneys in viral infections [6]. A more recent retrospective study by Dovč et al. [7] showed an AKI incidence of $71.4 \%$ of critically ill influenza patients, with $25 \%$ of acute renal failure and $28.6 \%$ overall mortality rate.

MERS-CoV infection usually causes severe extrapulmonary organ dysfunction, and most patients present with shock, acute kidney injury, and thrombocytopenia [8]. The exact mechanism of renal dysfunction is not well understood; however, studies have shown viral tropism for kidney cells ex vivo, suggesting MERS-CoV could induce apoptosis in the kidney $[9,10]$.

Pei et al. studied data from 333 patients hospitalized with COVID-19 pneumonia and showed that $75.4 \%$ demonstrated kidney injury [11]. Su et al. reported kidney abnormalities in 26 autopsies of patients with COVID-19 from which nine patients had clinical signs of kidney injury. The most significant findings were proximal tubule lesion, loss of brush border, and necrosis [12].

\section{Endocrine system}

Patients recovered from SARS have shown lipid and glucose metabolism abnormalities, with elevated levels of lysophosphatidylinositol (LPI) and phosphatidylinositol (PI), according to a study from $\mathrm{Wu}$ et al. [13]. As these lipids are involved in insulin metabolism, these changes could cause glucose metabolism abnormalities, increasing glucose tolerance, and insulin release.

Another study by Yang et al. found that SARS-related coronavirus can cause damage to the kidney, heart, lung, and endocrine part of the pancreas, likely due to increased expression of angiotensin-converting enzyme (ACE) receptors. In this study more than 50 percent of the patients became diabetic during hospitalization for the SARS-CoV infection. They suggested that coronavirus might enter the pancreas via ACE2 receptor causing acute islet cell dysfunction and hence reduces insulin release, leading to acute hyperglycemia and transient type 2 diabetes mellitus [14].

SARS has also been implicated in hypocortisolism and hypothyroidism in a group of 61 survivors of the viral infection. According to the authors, it might be due to a transient hypophysitis or direct hypothalamic effect caused by the virus [15].

Aloysius et al. described a case of severe acute pancreatitis in a patient diagnosed with COVID-19 [16]. Another case series reported on acute pancreatitis associated with SARSCoV-2 diagnosis. According to Hadi et al. two patients presented with elevated plasma amylase and image signs of acute pancreatitis. The authors hypothesized that direct viral invasion might be associated with enzyme activation, autodigestion, complement system activation, microcirculation disturbance, and necrosis [17].

One of the authors of this article reports on a case from his hospital in which a patient with a confirmed diagnosis of COVID-19 presenting with ground glass opacities on chest $\mathrm{CT}$, also presented with concomitant abdominal pain and increased levels of amylase, and was later diagnosed with acute pancreatitis (Fig. 1).

Although the present data are sparse, patients with adrenal insufficiency may be at higher risk of medical complications and mortality in the case of COVID-19 infection. European Society of Endocrinology recommends timely 
Fig. 1. Forty-year-old male presented to the emergency department with abdominal pain. Bilateral peripheral ground glass opacities are identified involving bilateral lung bases (a), the RT-PCR proven positive for COVID-19. Severe pancreatic edema and peripheral fat stranding are noted, in keeping with pancreatitis $(\mathbf{b}, \mathbf{c})$. The patient's serum amylase was above 1000
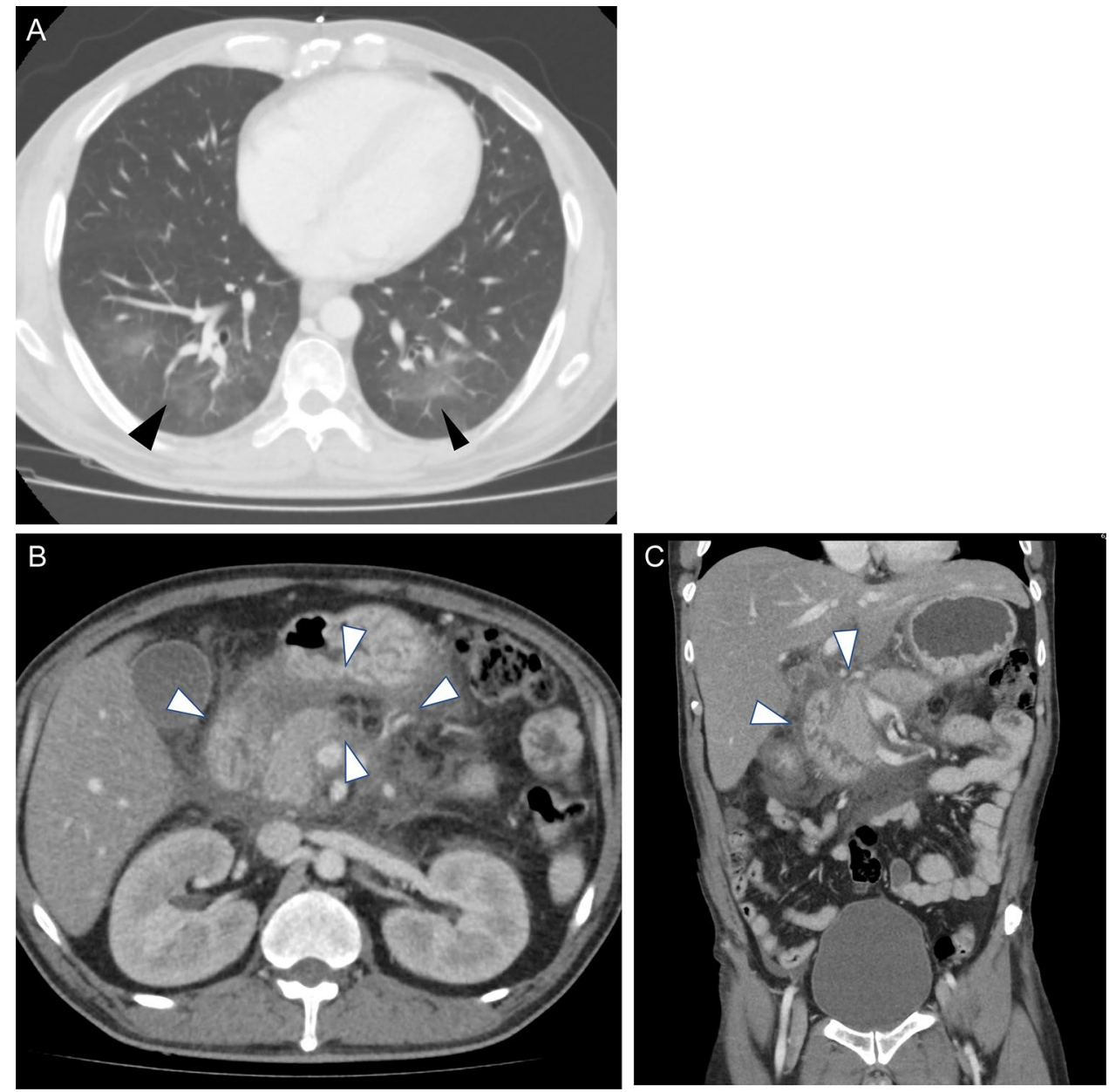

modification of the replacement treatment in these patients, when minor symptoms of infection appear, by at least doubling the usual doses of glucocorticoids so as to avoid adrenal crisis [18].

Undernourished patients diagnosed with COVID-19 infection may also be under higher risk of malnutrition due to the increased inflammatory body response and increased nutrient requirements. According to the European Society of Endocrinology a dense diet and adequate vitamin D supplementation must be offered for critically ill patients, with possible enteral or even parenteral nutrition if necessary [18].

\section{Liver injury}

Studies have reported a variety of liver abnormalities caused by SARS and MERS, including mild to moderately elevated transaminases, hypoalbuminemia, mild steatosis, congestion, and necrosis [19]. Chau et al. reported percutaneous liver biopsies in three patients that showed hepatocyte infection by SARS-CoV and elevated transaminases. The investigators found a marked accumulation of cells in mitosis and apoptosis [19]. The possible mechanism of invasion is through angiotensin-converting enzyme 2 (ACE2) receptors that are abundantly expressed on endothelial cells of the liver [20].

As found in SARS-infected patients, MERS causes mild inflammation in the liver. Still, the mechanism of entering the cell is different through other types of cell receptors (DDP-4), which also has high expressivity in hepatocytes [20, 21]. Liver function abnormalities associated with COVID-19 have also been described [22].

\section{Neurological and muscular abnormalities}

Coronaviruses can invade the nervous system causing a wide range of clinical neurological complications, which can be achieved by several routes, including trans-synaptic transfer, direct invasion via the olfactory nerve, endothelium, or migration across the blood-brain barrier [23]. Tsai et al. described neuromuscular symptoms in patients diagnosed with SARS: two patients presented motor-predominant peripheral nerve disorders, one developed myopathy, and another developed neuropathy and myopathy. All patients had clinical improvement and good outcome on follow-up [24]. Another case series reported three 
patients with SARS that developed rhabdomyolysis during treatment. However, all received succinylcholine for muscle blockade during ICU treatment, which might have influenced as a causative agent [25]. Influenza infection has also been associated with the development of myositis in 3\% of affected children involving most commonly the calf muscles, with high blood concentration of creatine phosphokinase [26]. Peripheral neuropathy has also been described in patients with SARS, and critical illness polyneuropathy should be considered as the cause [27].

Cerebral infarction may be associated with SARS, according to a case series of 206 patients, of which five developed ischemic strokes, although only two had previous risk factors [28]. The cause is unknown, although the use of intravenous immunoglobulin might be associated with this outcome $[29,30]$. Other hypothesized mechanisms could be a vasculitis or a hypercoagulable state [31, 32].

MERS has also been associated with the development of intracerebral hemorrhage as a result of thrombocytopenia, Disseminated Intravascular Coagulation (DIC), platelet dysfunction, and polyneuropathy after long ICU treatment, according to a case report by Algahtani et al. [33].

Encephalitis may be associated with influenza viral infection. However, it is difficult to isolate the virus from the brain or cerebrospinal fluid. Morishima et al. reported 148 cases of influenza-associated encephalitis during the seasonal epidemic of 1998-1999, in which $87.8 \%$ were caused by type A virus, most patients were children less than 5 years, and the major signs were altered consciousness and convulsions. The mortality rates were high (31.8\%), with rapid progression of symptoms and poor outcomes [34]. McCullers reported a case of a 6-year-old girl with influenza $\mathrm{B}$ infection and neurological sequelae. The patient presented with excessive somnolence that evolved to delirium and akinetic mutism [35]. Different types of encephalitis have been reported following influenza B infection [36]. The patient presented with lethargy, mutism, and the ECG showed slowed background activity. MRI was performed, and there was diffusion restriction and $\mathrm{T} 2$ hyperintensity on the corpus callosum and peripheral white matter. Cerebrospinal fluid was normal [36].

Protheroe et al. encephalitis postinfluenza A demonstrated hypodense lesions within the thalami and pons on head computed tomography and signal alterations in the pons on MRI in one case [37]. Yoshikawa studied 20 patients with influenza-associated encephalitis/encephalopathy during four seasons in Japan and found that clinical presentation varied among patients. They divided the patients according to the clinical presentation between those resembling Reye's syndrome, those that presented with shock symptoms and those with pontine, cerebellar, and brain stem symptoms. According to the authors, the high level of cytokines in these patients presented could be associated with neurological symptoms [38].

Regarding the current COVID-19 pandemic, several studies describe neurological symptoms and complications. Headache, anosmia, hypogeusia are frequently early symptoms of coronavirus infections [39]. Cerebral ischemia occurs probably due to viral invasion of endothelium resulting in vasculitis, coagulopathy, and thrombosis. Seizures, encephalopathy, meningitis, myelitis, Guillain-Barré, MillerFisher have also been described [39]. Invasion of the medullary cardiorespiratory center by coronavirus- 2 might be responsible for refractory respiratory failure in critically ill patients [40].

Facial paralysis can also occur following SARS-CoV-2 infections [41]. Morassi et al. reported six cases of patients with a diagnosis of COVID-19 that developed stroke during treatment, although all patients but one had pre-existing vascular risk factors. The outcome was poor, with five patients dying and one remaining severely neurologically affected [42].

Patients infected with COVID-19 have also presented symptoms of cranial peripheral neuropathy like internuclear ophthalmoparesis and oculomotor palsy [43]. It is important, though, to be aware that many neurological symptoms described in patients with these viral infections are nonspecific and have considerable overlap with other severe infections and generally there is no definitive confirmation of viral infection in the CSF of patients with SARS-CoV-2 [44].

Recent radiological reports added increasing evidence of central nervous system abnormalities in patients infected with SARS-CoV-2, particularly white matter signal alterations [45] that could involve the corpus callosum [46], but also several examples of acute necrotizing encephalopathy [47], acute ischemic infarcts [45, 48], microhemorrhages [49], basal ganglia abnormalities [50], encephalomyelitis, and meningitis, as well as cranial nerve and spinal nerve root abnormalities [51], highlighting the importance of neurological surveillance specially in critically ill patients [52].

\section{Cardiovascular abnormalities}

There is limited literature regarding cardiovascular involvement from SARS-CoV-1 infection, with some anecdotal data of patients with acute coronary syndrome, myocardial infarction, transient diastolic dysfunction, hypotension, bradycardia, transient cardiomegaly, and one postmortem study that showed thromboembolic disease [53-57]. Cardiovascular involvement in MERS also has limited systematic information. Most of the published works are from case reports or about the prevalence of comorbidities in affected patients [58]. Increased troponin and image signs of myocarditis were described in one case report [59]. 
Table 1 Summary of main extra-pulmonary manifestations of SARS, Influenza, MERS, and COVID-19

\begin{tabular}{|c|c|c|c|}
\hline Organ/system & Condition & Main finding & Method \\
\hline \multirow[t]{3}{*}{ Kidney } & Acute kidney injury & Acute tubular necrosis $[1,4,12]$ & Pathology $[1,4,12]$ \\
\hline & Proteinuria & Acute kidney injury $[2,3,5-7]$ & $\begin{array}{l}\text { Laboratory analysis (increase in serum } \\
\text { creatinine } \pm \text { proteinuria) }[2,3,5-7]\end{array}$ \\
\hline & & Cell apoptosis [9] & $\begin{array}{l}\text { In vitro, ex vivo, and in vivo molecular, } \\
\text { genetic, and pathology studies [9] }\end{array}$ \\
\hline \multirow[t]{7}{*}{ Endocrine } & Hypocortisolism & Increased serum lipids [13] & Lipid and metabolic profile, gas chroma- \\
\hline & Hypothyroidism & & tography-mass spectrometry, and liquid \\
\hline & Pancreatic islet cells injury & & \\
\hline & Pancreatitis & & \\
\hline & & $\begin{array}{l}\text { Binding of SARS Coronavirus-1 to its } \\
\text { receptor damages islets cells [14] }\end{array}$ & $\begin{array}{l}\text { Immunohistochemical staining of affected } \\
\text { tissues from donors }\end{array}$ \\
\hline & & Decreased serum cortisol levels [15] & Laboratory analysis [15] \\
\hline & & $\begin{array}{l}\text { Elevated serum lipase and amylase [16, } \\
17]\end{array}$ & Laboratory analysis $[16,17]$ \\
\hline \multirow[t]{3}{*}{ Liver } & Increased transaminases & $\begin{array}{l}\text { Increased viral load in parenchymal and } \\
\text { endothelial cells }\end{array}$ & Pathology analysis [20] \\
\hline & Portal inflammation & $\begin{array}{l}\text { Eosinophilic bodies, balloon-like hepato- } \\
\text { cytes, apoptosis [20] }\end{array}$ & \\
\hline & Hepatocyte apoptosis & $\begin{array}{l}\text { Increased DPP-4 receptor facilitating viral } \\
\text { infection [21] }\end{array}$ & Biopsy, immunohistochemical analysis [21] \\
\hline Pancreas & Increased serum pancreatic enzymes & $\begin{array}{l}\text { Edema and swelling of pancreas with } \\
\text { peripancreatic stranding on CT and MRI } \\
\text { (Fig. 1) }\end{array}$ & $\mathrm{CT}$ \\
\hline \multirow[t]{7}{*}{ Neuromuscular } & Encephalopathy & $\begin{array}{l}\text { White matter high signal intensity on } \\
\text { FLAIR }\end{array}$ & MRI and $\mathrm{CT}$ \\
\hline & Seizures & $\begin{array}{l}\text { Low CT attenuation on corpus callosum } \\
\text { and deep white matter }\end{array}$ & \\
\hline & Cerebral ischemia & Microhemorrhages [49] & \\
\hline & Myelitis & $\begin{array}{l}\text { High signal intensity on cerebellum and } \\
\text { diffusely in subcortical white matter, } \\
\text { basal ganglia [45-51] }\end{array}$ & \\
\hline & Peripheral neuropathy & Meningeal enhancement [50] & \\
\hline & Myositis & Perfusion abnormalities [50] & \\
\hline & & $\begin{array}{l}\text { Cranial nerve and spinal nerve root } \\
\text { enhancement [51] }\end{array}$ & \\
\hline \multirow[t]{4}{*}{ Cardiovascular } & Myocarditis & $\begin{array}{l}\text { Arterial thrombosis and pulmonary } \\
\text { thromboembolism }\end{array}$ & CT, MRI, PET, echocardiography \\
\hline & Myocardial infarction & Myocarditis, pericarditis [53-69] & \\
\hline & Pericarditis & & \\
\hline & Coagulopathy & & \\
\hline \multirow[t]{4}{*}{ Perinatal } & Miscarriage & Premature prelabor rupture of membranes & Clinical and Obstetric findings \\
\hline & Preterm premature membrane rupture & Preterm birth & \\
\hline & Growth Restriction & Preeclampsia & \\
\hline & Preeclampsia & Fetal growth restriction [70] & \\
\hline
\end{tabular}

Patients with COVID-19 diagnosis have been reported to present with arrhythmia and myocarditis [60]. In a case series five had some type of cardiac injury [61]. Guo et al. [62] studied 187 patients with a diagnosis of COVID-19 in which $52(27.8 \%)$ had a myocardial injury as indicated by elevated troponin levels, and the myocardial injury was significantly associated with fatal outcome. Tung-Chen
[63] reported acute pericarditis in a patient diagnosed with COVID-19 that presented with pleuritic pain and pericardial effusion that was resolved after treatment with colchicine. The mechanism of cardiac involvement is not clear but hypotheses direct to possible direct viral injury and secondary to inflammatory process [64]. 
COVID-19 patients have increased coagulation abnormalities. Some studies have pointed out to the contribution of the inflammatory response and activation of coagulation cascade [65]. These hypotheses have been corroborated by some reported cases of patients with thromboembolic complications after cytokine storm, despite having no risk factors for thromboembolism [66].

Recent case reports have added to the knowledge of cardiac abnormalities, including deteriorating myocardial function, myocarditis, pancarditis, pericardial effusions, artery thrombosis, and coronary artery aneurisms [67]. Pulmonary thromboembolism is particularly prevalent in severely ill patients and involves mainly segmental and sub-segmental arteries of pulmonary segments affected by consolidation, raising concerns of inflammatory and hypercoagulability factors contributing to its pathogenesis [68].

Some patients may present cardiac involvement without symptoms or signs of interstitial pneumonia, as reported by Riccardo et al. on a patient later diagnosed with myopericarditis [69].

\section{Gestational and perinatal abnormalities}

Coronaviruses may be associated with perinatal complications. Recently a systematic review on pregnancy-related complications from SARS, MERS, and COVID-19 showed and increased prevalence of preterm birth and miscarriage, along with fetal distress and necessity for ICU treatment [70].

\section{Discussion}

Several studies have reported extra-pulmonary conditions in patients diagnosed with SARS, Influenza, MERS, and COVID-19, affecting the kidneys, pancreas, liver, peripheral nerves, muscles, the endocrine glandules, myocardium, and pericardium. Most of the studies are case reports or case series, and in some cases, it is not possible to be sure if there is direct invasion by the viruses (Table 1).

\section{Conclusion}

Patients with a diagnosis of SARS, MERS, influenza, and COVID-19 frequently present extra-pulmonary symptoms that may be caused by direct virus injury or secondary to the systemic inflammatory response [71-78]. Acute kidney injury and proteinuria, pancreatitis, hypocortisolism, hypothyroidism, myositis, encephalopathy, perinatal complications, and myocarditis can be associated with these viral infections. The progression from pulmonary disease to a systemic condition has a poor outcome and can result in multi-organ failure and death.

Author contributions A.F.L., A.M.A., A.G., A.G. are guarantors of integrity of entire study; A.F.L., A.M.A., A.G. helped in study concepts; all authors contributed to manuscript drafting or manuscript revision for important intellectual content; approval of final version of submitted manuscript; literature research; and manuscript editing.

\section{Compliance with ethical standards}

Conflicts of interest The authors of this study have no conflicts of interest to declare.

Ethical standards This article does not contain any studies with human participants or animals performed by any of the authors.

\section{References}

1. Chu KH, Tsang WK, Tang CS, Lam MF, Lai FM, To KF et al (2005) Acute renal impairment in coronavirus-associated severe acute respiratory syndrome. Kidney Int 67(2):698-705. https:// doi.org/10.1111/j.1523-1755.2005.67130.x

2. Cha RH, Joh JS, Jeong I, Lee JY, Shin HS, Kim G, Kim Y (2015) Renal complications and their prognosis in Korean patients with middle east respiratory syndrome-coronavirus from the central MERS-CoV designated hospital. J Korean Med Sci 30(12):18071814. https://doi.org/10.3346/jkms.2015.30.12.1807

3. Watanabe T, Yoshikawa H, Abe Y, Yamazaki S, Uehara Y, Abe T (2003) Renal involvement in children with influenza A virus infection. PediatricNephrol 18(6):541-544. https://doi.org/10.1007/ s00467-003-1143-z

4. Cunningham E, Kohli R, Venuto RC (1979) Influenza-associated myoglobinuric renal failure. JAMA 242(22):2428-2429. https:// doi.org/10.1001/jama.1979.03300220040021

5. Morgensen JL (1974) Myoglobinuria and renal failure associated with influenza. Ann Intern Med 80(3):362-363

6. Shenouda A, Hatch FE (1976) Influenza a viral infection associated with acute renal failure. Am J Med 61(5):697-702. https:// doi.org/10.1016/0002-9343(76)90148-0

7. Dovč A, Premru V, Pečavar B, Ponikvar R (2017) Acute kidney injury in critically-ill adult patients with seasonal influenza infection. Clin Nephrol 88(13):18-21. https://doi.org/10.5414/cnp88 fx05

8. Arabi YM, Arifi AA, Balkhy HH, Najm H, Aldawood AS, Ghabashi A et al (2014) Clinical course and outcomes of critically ill patients with Middle East respiratory syndrome coronavirus infection. Ann Intern Med 160(6):389-397. https://doi. org/10.7326/m13-2486

9. Yeung M-L, Yao Y, Jia L, Chan JFW, Chan K-H, Cheung K-F et al (2016) MERS coronavirus induces apoptosis in kidney and lung by upregulating Smad7 and FGF2. Nat Microbiol 1(3):16004. https://doi.org/10.1038/nmicrobiol.2016.4

10. Eckerle I, Müller MA, Kallies S, Gotthardt DN, Drosten $C$ (2013) In-vitro renal epithelial cell infection reveals a viral kidney tropism as a potential mechanism for acute renal failure during Middle East respiratory syndrome (MERS) coronavirus infection. Virol J 10:359. https://doi. org/10.1186/1743-422x-10-359 
11. Pei G, Zhang Z, Peng J, Liu L, Zhang C, Yu C et al (2020) Renal Involvement and early prognosis in patients with COVID-19 pneumonia. J Am SocNephrol 31(6):1157-1165. https://doi. org/10.1681/asn.2020030276

12. Su H, Yang M, Wan C, Yi L-X, Tang F, Zhu H-Y et al (2020) Renal histopathological analysis of 26 postmortem findings of patients with COVID-19 in China. Kidney Int. https://doi. org/10.1016/j.kint.2020.04.003

13. Wu Q, Zhou L, Sun X, Yan Z, Hu C, Wu J et al (2017) Altered lipid metabolism in recovered SARS patients twelve years after infection. Sci Rep 7(1):9110. https://doi.org/10.1038/s4159 8-017-09536-Z

14. Yang JK, Lin SS, Ji XJ, Guo LM (2010) Binding of SARS coronavirus to its receptor damages islets and causes acute diabetes. Acta Diabetol 47(3):193-199. https://doi.org/10.1007/s0059 2-009-0109-4

15. Leow MK, Kwek DS, Ng AW, Ong KC, Kaw GJ, Lee LS (2005) Hypocortisolism in survivors of severe acute respiratory syndrome (SARS). Clin Endocrinol (Oxf) 63(2):197-202. https:// doi.org/10.1111/j.1365-2265.2005.02325.x

16. Aloysius MM, Thatti A, Gupta A, Sharma N, Bansal P, Goyal H (2020) COVID-19 presenting as acute pancreatitis. Pancreatology. https://doi.org/10.1016/j.pan.2020.05.003

17. Hadi A, Werge M, Kristiansen KT, Pedersen UG, Karstensen JG, Novovic S, Gluud LL (2020) Coronavirus disease-19 (COVID-19) associated with severe acute pancreatitis: case report on three family members. Pancreatology 20(4):665-667. https://doi.org/10.1016/j.pan.2020.04.021

18. Puig-Domingo M, Marazuela M, Giustina A (2020) COVID-19 and endocrine diseases. A statement from the European Society of Endocrinology. Endocrine 68(1):2-5. doi:https://doi. org/10.1007/s12020-020-02294-5

19. Kukla M, Skonieczna-Żydecka K, Kotfis K, Maciejewska D, Łoniewski I, Lara LF et al (2020) COVID-19, MERS and SARS with concomitant liver injury-systematic review of the existing literature. J Clin Med 9(5). doi:https://doi.org/10.3390/jcm90 51420

20. Xu L, Liu J, Lu M, Yang D, Zheng X (2020) Liver injury during highly pathogenic human coronavirus infections. Liver Int 40(5):998-1004. https://doi.org/10.1111/liv.14435

21. Raj VS, Mou H, Smits SL, Dekkers DH, Müller MA, Dijkman R et al (2013) Dipeptidyl peptidase 4 is a functional receptor for the emerging human coronavirus-EMC. Nature 495(7440):251-254. https://doi.org/10.1038/nature12005

22. Fan Z, Chen L, Li J, Tian C, Zhang Y, Huang S, Liu Z, Cheng J (2020) Clinical features of COVID-19 related liver damage. medRxiv:2020.2002.2026.20026971. doi:https://doi. org/10.1101/2020.02.26.20026971

23. Zubair AS, McAlpine LS, Gardin T, Farhadian S, Kuruvilla DE, Spudich S (2020) Neuropathogenesis and neurologic manifestations of the coronaviruses in the age of coronavirus disease 2019: a review. JAMA Neurol. https://doi.org/10.1001/jamaneurol .2020 .2065

24. Tsai LK, Hsieh ST, Chao CC, Chen YC, Lin YH, Chang SC, Chang YC (2004) Neuromuscular disorders in severe acute respiratory syndrome. Arch Neurol 61(11):1669-1673. https://doi. org/10.1001/archneur.61.11.1669

25. Wang JL, Wang JT, Yu CJ, Chen YC, Hsueh PR, Hsiao CH, Kao CL, Chang SC, Yang PC (2003) Rhabdomyolysis associated with probable SARS. Am J Med 115(5):421-422. https://doi. org/10.1016/s0002-9343(03)00448-0

26. Agyeman P, Duppenthaler A, Heininger U, Aebi C (2004) Influenza-associated myositis in children. Infection 32(4):199-203. https://doi.org/10.1007/s15010-004-4003-2

27. Chao CC, Tsai LK, Chiou YH, Tseng MT, Hsieh ST, Chang SC, Chang YC (2003) Peripheral nerve disease in SARS: report of a case. Neurology 61(12):1820-1821. https://doi.org/10.1212/01. wnl.0000099171.26943.d0

28. Umapathi T, Kor AC, Venketasubramanian N, Lim CC, Pang BC et al (2004) Large artery ischaemic stroke in severe acute respiratory syndrome (SARS). J Neurol 251(10):1227-1231. https://doi. org/10.1007/s00415-004-0519-8

29. Dalakas MC, Clark WM (2003) Strokes, thromboembolic events, and IVIg: rare incidents blemish an excellent safety record. Neurology 60(11):1736-1737. https://doi.org/10.1212/01.wnl.00000 74394.15882 .83

30. Okuda D, Flaster M, Frey J, Sivakumar K (2003) Arterial thrombosis induced by IVIg and its treatment with tPA. Neurology 60(11):1825-1826. https://doi.org/10.1212/01.wnl.0000068334 .04500 .08

31. Ding Y, Wang H, Shen H, Li Z, Geng J, Han H, Cai J, Li X, Kang W, Weng D, Lu Y, Wu D, He L, Yao K (2003) The clinical pathology of severe acute respiratory syndrome (SARS): a report from China. J Pathol 200(3):282-289. https://doi.org/10.1002/ path. 1440

32. Tsai LK, Hsieh ST, Chang YC (2005) Neurological manifestations in severe acute respiratory syndrome. Acta Neurol Taiwan 14(3):113-119

33. Kim J-E, Heo J-H, Kim H-o, Song S-h, Park S-S, Park T-H, Ahn J-Y, Kim M-K, Choi J-P (2017) Neurological complications during treatment of Middle East Respiratory syndrome. J ClinNeurol 13(3):227-233

34. Morishima T, Togashi T, Yokota S, Okuno Y, Miyazaki C, Tashiro M, Okabe N (2002) Encephalitis and encephalopathy associated with an influenza epidemic in Japan. Clin Infect Dis 35(5):512 517. https://doi.org/10.1086/341407

35. McCullers JA, Facchini S, Chesney PJ, Webster RG (1999) Influenza B virus encephalitis. Clin Infect Dis 28(4):898-900. https:// doi.org/10.1086/515214

36. Vanderschueren G, Schotsmans K, Maréchal E, Crols R (2018) Mild encephalitis with reversible splenial (MERS) lesion syndrome due to influenza B virus. Pract Neurol 18(5):391-392. https ://doi.org/10.1136/practneurol-2018-001880

37. Protheroe SM, Mellor DH (1991) Imaging in influenza A encephalitis. Arch Dis Child 66(6):702-705. https://doi.org/10.1136/ adc.66.6.702

38. Yoshikawa H, Yamazaki S, Watanabe T, Abe T (2001) Study of influenza-associated encephalitis/encephalopathy in children during the 1997 to 2001 influenza seasons. J Child Neurol 16(12):885-890. https://doi.org/10.1177/088307380101601204

39. Román GC, Spencer PS, Reis J, Buguet A, Faris MEA, Katrak SM et al (2020) The neurology of COVID-19 revisited: a proposal from the Environmental Neurology Specialty Group of the World Federation of Neurology to implement international neurological registries. J Neurol Sci 414:116884. https://doi.org/10.1016/j. jns.2020.116884

40. Montalvan V, Lee J, Bueso T, De Toledo J, Rivas K (2020) Neurological manifestations of COVID-19 and other coronavirus infections: a systematic review. ClinNeurolNeurosurg 194:105921. https://doi.org/10.1016/j.clineuro.2020.105921

41. Juliao Caamaño DS, Alonso Beato R (2020) Facial diplegia, a possible atypical variant of Guillain-Barré syndrome as a rare neurological complication of SARS-CoV-2. J Clin Neurosci. https ://doi.org/10.1016/j.jocn.2020.05.016

42. Morassi M, Bagatto D, Cobelli M, D'Agostini S, Gigli GL, Bnà C, Vogrig A (2020) Stroke in patients with SARS-CoV-2 infection: case series. J Neurol. https://doi.org/10.1007/s00415-020-09885 $-2$

43. Gutiérrez-Ortiz C, Méndez A, Rodrigo-Rey S, San Pedro-Murillo E, Bermejo-Guerrero L, Gordo-Mañas R, de Aragón-Gómez F, Benito-León J (2020) Miller Fisher syndrome and polyneuritis 
cranialis in COVID-19. Neurology. doi:https://doi.org/10.1212/ wnl.0000000000009619

44. Needham EJ, Chou SHY, Coles AJ, Menon DK (2020) Neurological implications of COVID-19 infections. Neurocrit Care 32(3):667-671. https://doi.org/10.1007/s12028-020-00978-4

45. Kremer S, Lersy F, de Sèze J, Ferré J-C, Maamar A, Carsin-Nicol B, Collange O, Bonneville F, Adam G, Martin-Blondel G (2020) Brain MRI findings in severe COVID-19: a retrospective observational study. Radiology. 202222

46. Sachs JR, Gibbs KW, Swor DE, Sweeney AP, Williams DW, Burdette JH, West TG, Geer CP (2020) COVID-19-Associated Leukoencephalopathy. Radiology. 201753

47. Poyiadji N, Shahin G, Noujaim D, Stone M, Patel S, Griffith B (2020) COVID-19-associated acute hemorrhagic necrotizing encephalopathy: CT and MRI features. Radiology. 201187

48. Mahammedi A, Saba L, Vagal A, Leali M, Rossi A, Gaskill $M$ et al (2020) Imaging in neurological disease of hospitalized COVID-19 patients: an Italian multicenter retrospective observational study. Radiology. 201933-201933

49. Radmanesh A, Derman A, Lui YW, Raz E, Loh JP, Hagiwara M et al (2020) COVID-19-associated diffuse leukoencephalopathy and microhemorrhages. Radiology 297(1):E223-E227

50. Chougar L, Shor N, Weiss N, Galanaud D, Leclercq D, Mathon B et al (2020) Retrospective observational study of brain magnetic resonance imaging findings in patients with acute SARS-CoV-2 infection and neurological manifestations. Radiology. 202422

51. Klironomos S, Tzortzakakis A, Kits A, Öhberg C, Kollia E, Ahoromazdae A et al (2020) Nervous system involvement in COVID19: results from a retrospective consecutive neuroimaging cohort. Radiology. 202791

52. Katal S, Balakrishnan S, Gholamrezanezhad A (2020) Neuroimaging findings in COVID-19 and other coronavirus infections: a systematic review in 116 patients. J Neuroradiol

53. Madjid M, Safavi-Naeini P, Solomon SD, Vardeny O (2020) Potential effects of coronaviruses on the cardiovascular system: a review. JAMA Cardiol. https://doi.org/10.1001/jamacardio .2020 .1286

54. Peiris JS, Chu CM, Cheng VC, Chan KS, Hung IF, Poon LL, Law KI, Tang BS, Hon TY, Chan CS, Chan KH, Ng JS, Zheng BJ, Ng WL, Lai RW, Guan Y, Yuen KY (2003) Clinical progression and viral load in a community outbreak of coronavirus-associated SARS pneumonia: a prospective study. Lancet 361(9371):17671772. https://doi.org/10.1016/s0140-6736(03)13412-5

55. Chong PY, Chui P, Ling AE, Franks TJ, Tai DY, Leo YS et al (2004) Analysis of deaths during the severe acute respiratory syndrome (SARS) epidemic in Singapore: challenges in determining a SARS diagnosis. Arch Pathol Lab Med 128(2):195-204. https://doi.org/10.1043/1543-2165(2004)128\%3c195:Aoddt s\%3e2.0.Co;2

56. Yu CM, Wong RS, Wu EB, Kong SL, Wong J, Yip GW et al (2006) Cardiovascular complications of severe acute respiratory syndrome. Postgrad Med J 82(964):140-144. https://doi. org/10.1136/pgmj.2005.037515

57. Li SS, Cheng CW, Fu CL, Chan YH, Lee MP, Chan JW, Yiu SF (2003) Left ventricular performance in patients with severe acute respiratory syndrome: a 30-day echocardiographic follow-up study. Circulation 108(15):1798-1803. https://doi.org/10.1161/01. Cir.0000094737.21775.32

58. Badawi A, Ryoo SG (2016) Prevalence of comorbidities in the Middle East respiratory syndrome coronavirus (MERS-CoV): a systematic review and meta-analysis. Int J Infect Dis 49:129-133. https://doi.org/10.1016/j.ijid.2016.06.015

59. Alhogbani T (2016) Acute myocarditis associated with novel Middle east respiratory syndrome coronavirus. Ann Saudi Med 36(1):78-80. https://doi.org/10.5144/0256-4947.2016.78
60. Wang D, Hu B, Hu C, Zhu F, Liu X, Zhang J et al (2020) Clinical characteristics of 138 hospitalized patients With 2019 Novel coronavirus-Infected pneumonia in Wuhan, China. JAMA 323(11):1061-1069. https://doi.org/10.1001/jama.2020.1585

61. Huang C, Wang Y, Li X, Ren L, Zhao J, Hu Y et al (2020) Clinical features of patients infected with 2019 novel coronavirus in Wuhan, China. Lancet 395(10223):497-506. https://doi. org/10.1016/S0140-6736(20)30183-5

62. Guo T, Fan Y, Chen M, Wu X, Zhang L, He T, Wang H, Wan J, Wang X, Lu Z (2020) Cardiovascular implications of fatal outcomes of patients with coronavirus disease 2019 (COVID-19). JAMA Cardiol. https://doi.org/10.1001/jamacardio.2020.1017

63. Tung-Chen Y (2020) Acute pericarditis due to COVID-19 infection: An underdiagnosed disease? Med Clin (Barc). https://doi. org/10.1016/j.medcli.2020.04.007

64. Clerkin KJ, Fried JA, Raikhelkar J, Sayer G, Griffin JM, Masoumi A et al (2020) COVID-19 and cardiovascular disease. Circulation 141(20):1648-1655. https://doi.org/10.1161/circulatio naha.120.046941

65. Levi M, Thachil J (2020) Coronavirus disease 2019 coagulopathy: disseminated intravascular coagulation and thrombotic microangiopathy-either, neither, or both. SeminThrombHemost. https://doi. org/10.1055/s-0040-1712156

66. Griffin DO, Jensen A, Khan M, Chin J, Chin K, Parnell R et al (2020) Arterial thromboembolic complications in COVID-19 in low-risk patients despite prophylaxis. Br J Haematol. https://doi. org/10.1111/bjh.16792

67. Hameed S, Elbaaly H, Reid CE, Santos RM, Shivamurthy V, Wong J, Jogeesvaran KH (2020) Spectrum of imaging findings on chest radiographs, US, CT, and MRI images in multisystem inflammatory syndrome in children (MIS-C) associated with COVID-19. Radiology. 202543

68. Cavagna E, Muratore F, Ferrari F (2020) Pulmonary thromboembolism in COVID-19: venous thromboembolism or arterial thrombosis? Radiol Cardiothorac Imaging 2(4):e200289

69. Inciardi RM, Lupi L, Zaccone G, Italia L, Raffo M, Tomasoni D, Cani DS, Cerini M, Farina D, Gavazzi E (2020) Cardiac involvement in a patient with coronavirus disease 2019 (COVID-19). JAMA Cardiol 5(7):819-824

70. Di Mascio D, Khalil A, Saccone G, Rizzo G, Buca D, Liberati M, Vecchiet J, Nappi L, Scambia G, Berghella V, D’Antonio F (2020) Outcome of coronavirus spectrum infections (SARS, MERS, COVID 1-19) during pregnancy: a systematic review and metaanalysis. Am J Obstet Gynecol MFM 2(2):100107. https://doi. org/10.1016/j.ajogmf.2020.100107

71. Eslambolchi A, Aghaghazvini L, Gholamrezanezhad A, Kavosi $\mathrm{H}$, Radmard AR (2020) Coronavirus disease 2019 (COVID-19) in patients with systemic autoimmune diseases or vasculitis: radiologic presentation. J Thromb Thrombolysis. Epub ahead of print. PMID: 32981005; PMCID: PMC7519703

72. Cozzi D, Albanesi M, Cavigli E, Moroni C, Bindi A, Luvarà S, et al (2020) Chest X-ray in new coronavirus disease 2019 (COVID-19) infection: findings and correlation with clinical outcome. Radiol Med 125(8):730-737. doi: https://doi.org/10.1007/ s11547-020-01232-9. Epub 2020 Jun 9. PMID: 32519256; PMCID: PMC7282464

73. Behzad S, Aghaghazvini L, Radmard AR, Gholamrezanezhad A (2020) Extrapulmonary manifestations of COVID-19: radiologic and clinical overview. Clin Imaging 66:35-41. doi: https://doi. org/10.1016/j.clinimag.2020.05.013. Epub 2020 May 18. PMID: 32425338; PMCID: PMC7233216

74. Cozzi D, Moroni C, Addeo G, Danti G, Lanzetta MM, Cavigli E et al (2018) Radiological patterns of lung involvement in inflammatory bowel disease. Gastroenterol Res Pract 12(2018):5697846. https://doi.org/10.1155/2018/5697846.PMID:30158965;PMCID :PMC6109524 
75. Salehi S, Abedi A, Gholamrezanezhad A (2020) Reply to "Vascular changes detected with thoracic CT in coronavirus disease (COVID-19) might be significant determinants for accurate diagnosis and optimal patient management". AJR Am J Roentgenol 215(1):W16. doi: https://doi.org/10.2214/AJR.20.23339. Epub 2020 Apr 24. PMID: 32330077

76. Floridi C, Fogante M, Agostini A, Borgheresi A, Cellina M, Natella R et al (2020) Radiological diagnosis of coronavirus disease 2019 (COVID-19): a Practical guide. Acta Biomed 91(8S):51-59. doi: https://doi.org/10.23750/abm.v91i8-S.9973. PMID: 32945279

77. Katal S, Amini H, Gholamrezanezhad A (2020) PET in the diagnostic management of infectious/inflammatory pulmonary pathologies: a revisit in the era of COVID-19. Nucl Med Commun. Epub ahead of print. PMID: 32991395

78. Behzad S, Velez E, Najafi MH, Gholamrezanezhad A (2020) Coronavirus disease 2019 (COVID-19) pneumonia incidentally detected on coronary CT angiogram: a do-not-miss diagnosis. Emerg Radiol. doi: https://doi.org/10.1007/s10140-020-01802 -4. Epub ahead of print. PMID: 32519293; PMCID: PMC7280472

Publisher's Note Springer Nature remains neutral with regard to jurisdictional claims in published maps and institutional affiliations. 